\title{
An adjuvant free mouse model of oral allergenic sensitization to rice seeds protein
}

\author{
Xiao-Wei Chen, Ken Wan-Keung Lau, Fan Yang, Samuel Sai-Ming Sun and Ming-Chiu Fung ${ }^{*}$
}

\begin{abstract}
Background: Rice is commonly known as a staple crop consumed worldwide, though with several rice proteins being reported for allergic properties in clinical studies. Thus, there is a growing need for the development of an animal model to better understand the allergenicity of rice proteins and the immunological and pathophysiological mechanisms underlying the development of food allergy.

Methods: Groups of BALB/C mice were sensitized daily with freshly homogenized rice flour (30 mg or $80 \mathrm{mg}$ ) without adjuvant by intragastric gavage. In addition, the mice were challenged with extracted rice flour proteins at several time points intragastrically. Hypersensitivity symptoms in mice were evaluated according to a scoring system. Vascular leakage, ELISA of rice protein-specific lgE, histopathology of small intestine, and passive cutaneous anaphylaxis were conducted on challenged mice.

Results: An adjuvant free mouse model of rice allergy was established with sensitized mice showing increased scratching behaviors and increased vascular permeability. Rice protein-specific lgE was detected after eighteen days of sensitization and from the fifth challenge onwards. Inflammatory damage to the epithelium in the small intestine of mice was observed beyond one month of sensitization. Passive cutaneous anaphylaxis results confirmed the positive rice allergy in the mouse model.

Conclusions: We introduced a BALB/c mouse model of rice allergy with simple oral sensitization without the use of adjuvant. This model would serve as a useful tool for further analysis on the immunopathogenic mechanisms of the various rice allergens, for the evaluation of the hypersensitivity of rice or other cereal grains, and to serve as a platform for the development of immunotherapies against rice allergens.
\end{abstract}

\section{Background}

Rice, a major staple crop, is consumed by more than half of the world's population, especially in East Asia [1]. Multiple investigations show that rice may lead to a certain degree of hypersensitivity. Direct contact with raw rice, inhalation of rice pollen or vapor from boiling rice, and oral ingestion of cooked rice are a few defined routes that may trigger rice allergy [2-4]. Since the first identification of allergenicity from the rice protein fractions containing albumin, globulin and glutelin [5], rice allergy has been reported in many countries around the world, such as Japan, Malaysia, Thailand, Indonesia, and some European countries like Finland, France, Sweden, Denmark, Estonia, Lithuania, and Russia [2].

\footnotetext{
* Correspondence: mingchiufung@cuhk.edu.hk

Biology Program, School of Science Life Sciences, The Chinese University of Hong Kong, Shatin, Hong Kong SAR, China
}

Rice hypersensitivity has been mainly defined as IgEmediated reactions which ranged from mild urticaria to anaphylactic reactions [6-8]. There are also some evidences suggesting that rice is the most common solid food causing food protein-induced enterocolitis syndrome (FPIES), which is defined as a non-IgE-mediated gastrointestinal food hypersensitivity disorder $[9,10]$. Although several rice allergens have been identified, the immunopathogenic mechanisms responsible for IgEand cell-mediated systemic reactions are not well characterized. Murine model has been considered a good experimental system for studying the pathological mechanisms of food allergy $[11,12]$. However, such model of rice allergy has yet to be established and the mechanisms for hypersensitivity caused by rice proteins await detailed elucidation.

The purpose of this study is to establish a rice allergy mouse model using a simple protocol: daily sensitization
C Biomed Central

(c) 2011 Chen et al; licensee BioMed Central Ltd. This is an Open Access article distributed under the terms of the Creative Commons Attribution License (http://creativecommons.org/licenses/by/2.0), which permits unrestricted use, distribution, and reproduction in any medium, provided the original work is properly cited. 
with rice flour through the oral route without adjuvant to mimic the natural human exposure to ingested rice, as well as the experience of multiple intragastric challenges caused by rice total protein hypersensitivity.

\section{Methods}

\section{Rice protein (RP) extraction and electrophoresis}

Rice (Oryza sativa L. subsp. japonica) proteins extraction was conducted as described by Ju and Hettiarachchy [13], with little modifications. Briefly, after defatted with $\mathrm{n}$-hexane (Fairfield, OH, USA), dried rice flour was processed by four volumes of distilled water, $5 \% \mathrm{NaCl}$ (Sigma-Aldrich, St Louis, MO, USA), $0.02 \mathrm{M} \mathrm{NaOH}$ (Sigma-Aldrich), and 70\% ethanol (Scharlau Chemie SA, Barcelona, Spain) for the extraction of albumin, globulin, glutelin and prolamin, respectively. All extractions were performed by shaking at $20^{\circ} \mathrm{C}$ for $4 \mathrm{~h}$ and centrifuged at $17,700 \mathrm{~g}$ with the exception that glutelin was extracted by shaking at $20^{\circ} \mathrm{C}$ for $30 \mathrm{~min}$. Each extraction was repeated twice. The supernatants were collected and filtered. Albumin, globulin, and glutelin were precipitated by adjusting the $\mathrm{pH}$ to match their corresponding isoelectric points. Prolamin was precipitated by adding double volume of acetone (VWR Scientific, Suwanee, GA, USA) to the supernatant. The precipitated RPs (albumin, globulin, glutelin, and prolamin) were washed twice with distilled water, adjusted to $\mathrm{pH} 7.0$, freezedried and stored at $4{ }^{\circ} \mathrm{C}$. Protein concentrations were determined by following the Kjeldahl's method (AAAC, 1983). Sodium dodecyl sulfate - polyacrylamide gel electrophoresis (SDS-PAGE) was carried out under reducing conditions on $12.5 \%$ polyacrylamide gel. Proteins were visualized with Coomassie Blue staining (Bio-Rad Laboratories, Hercules, CA, USA).

\section{Rice sensitization and challenge protocol}

Female BALB/c mice (6 - 8 weeks old) were purchased from the Laboratory Animal Services Centre of the Chinese University of Hong Kong (Hong Kong SAR, China). The animals were maintained on rice-free diet and kept in a temperature controlled room $\left(23 \pm 2^{\circ} \mathrm{C}\right)$ with a $12 \mathrm{~h}$ light: $12 \mathrm{~h}$ dark cycle. All animal procedures were approved by the Animal Experimentation Ethics Committee of the Chinese University of Hong Kong, in accordance with the Department of Health (Hong Kong) guidelines in Care and Use of Animals. All experiments were performed under licenses granted from the Hong Kong Special Administrative Region Government.

Three groups each with $6 \mathrm{BALB} / \mathrm{c}$ mice were included in this study. In two experimental groups, mice were daily sensitized by intragastic gavage (i.g.) of $30 \mathrm{mg}$ or $80 \mathrm{mg}$ freshly homogenized rice flour. Upon each specified time point (day 4, 7, 11, 14, 18, 21, 25, and 28 after the course of sensitization), mice were orally challenged with $30 \mathrm{mg}$ of the extracted rice flour proteins. Control mice received an equal volume of phosphate buffered saline (PBS) for daily sham sensitization and challenge (Figure 1). All materials used to feed the mice were homogenized or dissolved in $1 \mathrm{ml}$ PBS solution. Before each challenge, mice were bled from the submandibular veins [14]. Sera were collected and subsequently stored at $-80^{\circ} \mathrm{C}$ until use.

\section{Assessment of hypersensitivity responses}

Symptoms of hypersensitivity were evaluated within 1$1.5 \mathrm{~h}$ after each challenge using a scoring system previously reported and scored as followed: $0=$ no symptoms; 1 = scratching and rubbing around the nose and head; 2 = puffiness around the eyes and mouth, pilar erecti, reduced activity, and/or decreased activity with increased respiratory rate; 3 = wheezing, labored respiration, and cyanosis around the mouth and the tail; $4=$ no activity after prodding or tremor and convulsion; and $5=$ death [15].

\section{Detection of vascular leakage}

To assess the vascular permeability, 3 to 5 mice from each group received $100 \mu \mathrm{l}$ of $0.5 \%$ Evan's blue Dye (Sigma) through tail vein injection immediately before the sixth intragastric RP challenge. Footpads of mice were recorded for signs of vascular leakage (visible bluing) within 1-1.5 $\mathrm{h}$ after dye/antigen administration.

\section{Passive cutaneous anaphylaxis test}

Pooled sera were obtained from each group of mice experienced different sensitization. Passive cutaneous anaphylaxis (PCA) test were performed as what has been previously described with slight modifications

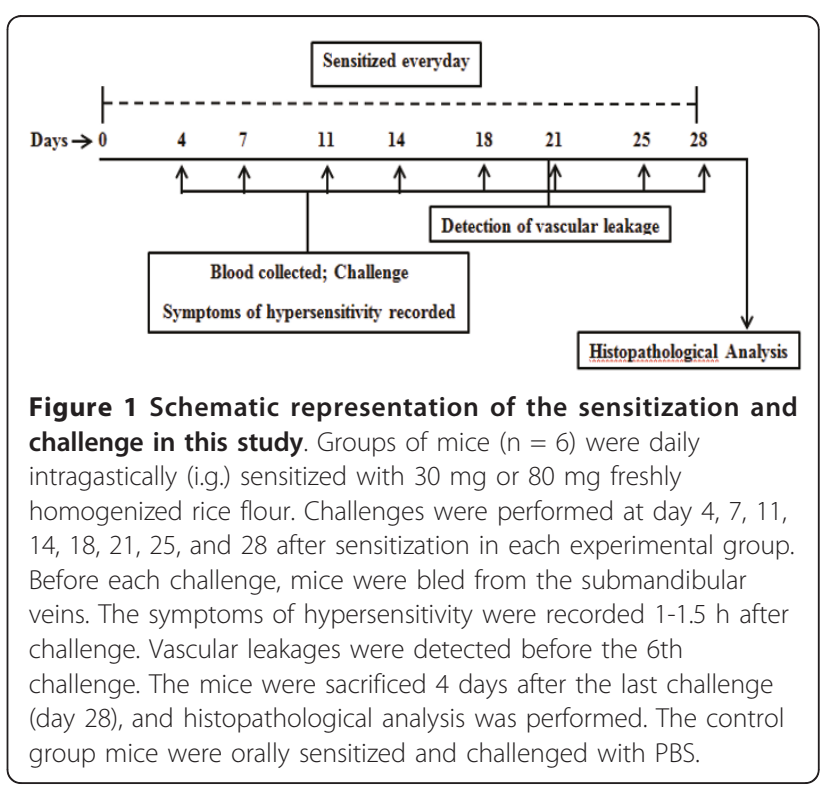


$[15,16]$. The abdomens of four naïve mice were shaved and four injection sites on each mouse were marked (three repeated experimental sites and one negative control site). On the first day, mice were injected with $50 \mu \mathrm{l}$ heated sera $\left(56^{\circ} \mathrm{C}\right.$ for 3 hours) from the $80 \mathrm{mg}$ rice flour proteins sensitized mice group or unheated sera (undiluted) from each group respectively. Control mice received an equal amount of naïve serum. After twenty-four hours, mice were re-injected at the same sites again with $50 \mu \mathrm{l}$ pooled same sera as the first injection. After an additional $3 \mathrm{~h}$, mice were injected intravenously with $100 \mu \mathrm{l}$ of $0.5 \%$ Evan's blue dye followed by intradermal injection of $50 \mu \mathrm{l}$ rice flour protein $(2 \mathrm{mg} / \mathrm{ml})$. PBS injection was applied to the control site of each mouse. Thirty minutes after the dye/antigen injection, the mice were killed; the skin of the abdomen was inverted, and observed for visible bluing. Results were scored as positive if the bluing of the skin at the injection sites was greater than $3 \mathrm{~mm}$ in any cross-section diameter.

\section{Histopathological analysis}

Segments of small intestine (jejunum) were embedded in paraffin after fixation in 10\% neutral-buffered formaldehyde (formaldehyde, $3.7 \%$; sodium phosphate monobasic, $0.4 \%$; sodium phosphate dibasic anhydrous, $0.65 \%$ ). Five-micrometer sections were stained with hematoxylin and eosin (H\&E). The morphology of the small intestine was photographed using a Nikon Eclipse 80i image-processing system (Nikon Inc., Melville, NY, USA).

\section{Measurement of RP-specific IgE in sera}

Rice protein-specific IgE was assayed by enzyme-linked immunosorbant assay (ELISA). Plates (Nunc-Immunoplate; PolySorp, Roskilde, Denmark) were coated with $100 \mu \mathrm{g} / \mathrm{ml}$ rice protein extract diluted in $50 \mu \mathrm{l}$ carbonate buffer $(\mathrm{pH} 9.6)$ at $4{ }^{\circ} \mathrm{C}$ for overnight. Plates were then washed 3 times with $200 \mu \mathrm{l}$ washing buffer and blocked with $75 \mu \mathrm{l} 1 \%$ bovine serum albumin (BSA) in PBS for one hour at $37^{\circ} \mathrm{C}$. After washing for 3 times, $50 \mu \mathrm{l}$ undiluted serum samples were added to the plates and incubated overnight at $4{ }^{\circ} \mathrm{C}$. Following incubation, plates were washed, and $50 \mu \mathrm{l}$ of 1:1000 diluted biotin anti-mouse IgE (BioLegend Corp., San Diego, CA, USA) was added to each well. The plates were further incubated for one hour at $37^{\circ} \mathrm{C}$. After 3 washes, $50 \mu \mathrm{l}$ of 1:2000 diluted horseradish peroxidase (HRP)conjugated streptavidin (BioLegend) was added and incubated for another hour at room temperature. The reactions were developed with 3,3',5,5'-tetramethylbenzidine liquid substrate (Sigma-Aldrich) for 30 minutes at room temperature, stopped with the addition of $1 \mathrm{~N}$ $\mathrm{H}_{2} \mathrm{SO} 4$, and optical density were taken at $450 \mathrm{~nm}$ wavelength.

\section{Statistics}

Statistical significance $(\mathrm{P}<0.05)$ of differences between individual mice groups was assessed by Student's t-test and one-way ANOVA with the help of Grpahpad Prism 5 (GraphPad Software, Inc. San Diego, CA). Data were expressed as mean $\pm \mathrm{SD}$.

\section{Results}

\section{Rice proteins (RP) extraction and electrophoresis}

Aiming at introducing total raw rice allergens to mouse, our protocol for RP extraction was designed to extract rice proteins to the largest extent. The average recovery efficience of our prototol for four major precipitated rice protein components (albumin, globulin, glutelin, and prolamin) varied from $88.1 \%$ to $91.0 \%$ in three independent experiments. The SDS-PAGE pattern of RP showed a large variety of proteins, ranging from $10 \mathrm{kDa}$ to $110 \mathrm{kDa}$ (Figure 2), including 14-16, 26, 33, 56, and $60 \mathrm{kDa}$ allergens [17-20]. This raw rice seeds flour was quantitated and the ectracted total RP was detected and

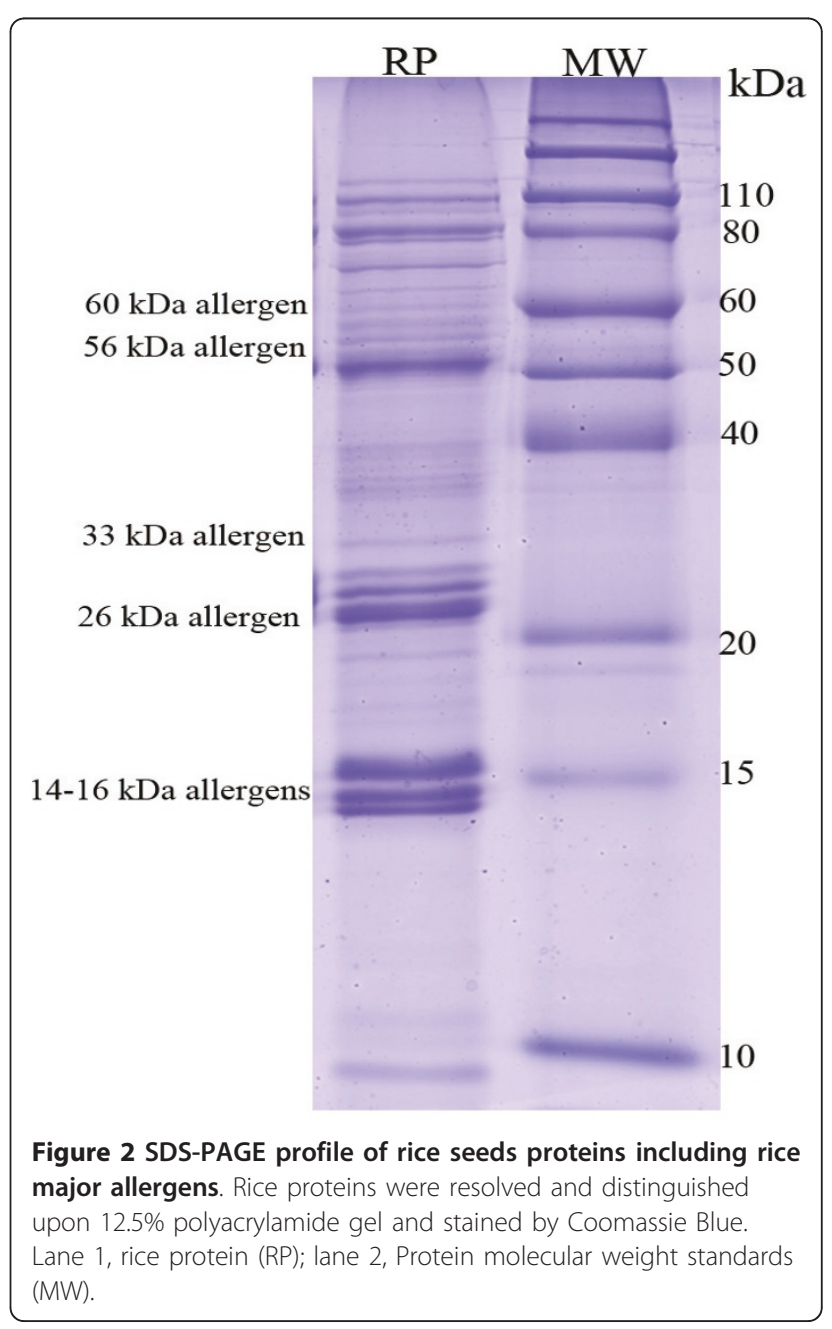


applied to BALB/c mice sensitization and challenge protocol, as described above.

\section{Hypersensitivity symptom induced by i.g. challenge}

At day 18, after the fifth intragastric challenge, all mice in the higher dose RP challenged group and four out of six mice in the lower dose group showed hypersensitivity reactions. No allergic reactions were detected among the PBS sham-sensitized mice (Figure 3).

\section{Vascular leakage after i.g. challenge}

The histamine release led to increased vascular permeability, which is regarded as a hallmark of hypersensitivity reaction. Figure 4 presents the bluish coloring of the footpads of challenged mice, which were unnoticeable in sham-sensitized mice after i.g. challenge.

\section{PCA reactions}

Based on the evidence that IgE levels account for most of the rice elicited hypersensitivity and are associated with the severity of anaphylaxis [19], we performed PCA assay to confirm the presence of rice antigen specific IgE in sera (Table 1). IgG1 specific hypersensitivity reactions were eliminated through PCA positive bluing demonstrated by naïve mice injected with unheated RPimmune sera but negative bluing with the heated one.

\section{Characterization of Intestinal Pathology}

Histologic examination of the jejunum segments revealed villi edema, lymphocytes infiltration and goblet

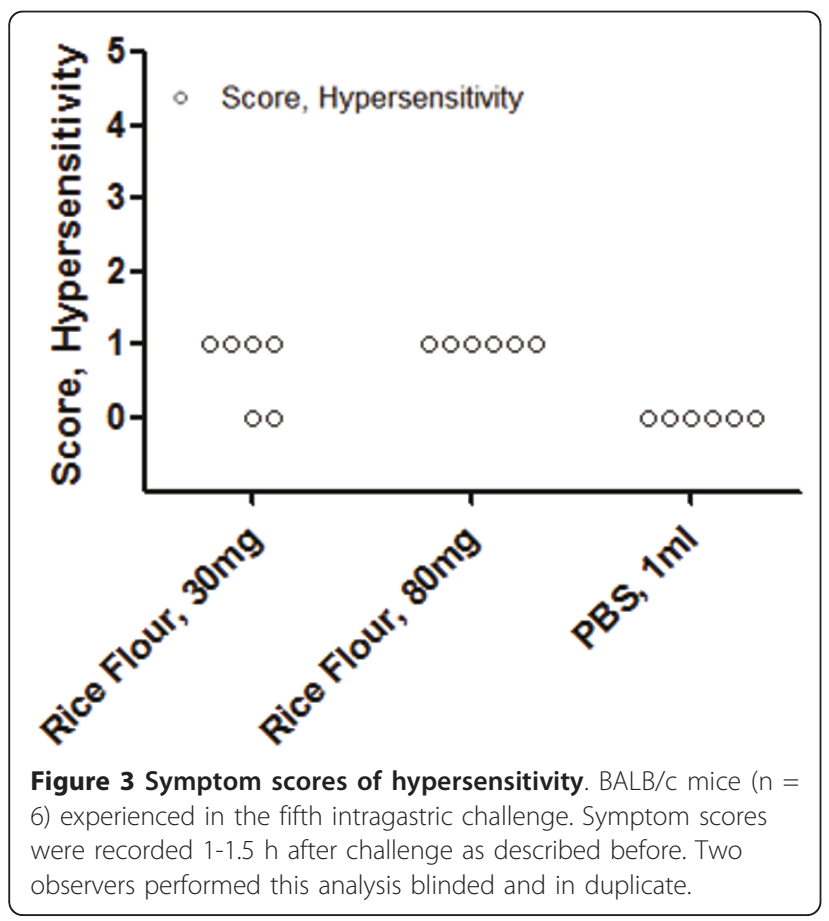

cells hyperplasia in mice sensitized with $30 \mathrm{mg}$ or 80 $\mathrm{mg}$ rice flour and challenged with $30 \mathrm{mg}$ rice total protein (Figure 5A, B vs Figure 5C).

\section{RP-specific IgE in sera after intragastric sensitization}

In order to better characterize the RP-specific IgE production during the course of murine rice allergy development, we further detected the serum RP-IgE level before every time point of challenge by ELISA. After the fifth challenge, a significant increase in RP-specific IgE can be observed from day 18 (Figure 6). Mice sensitized with larger dose $(80 \mathrm{mg} /$ day $)$ of raw rice seeds flour developed more antigen-specific IgE. RP-specific IgE production in our mice model exhibited both a dosedependent and time-dependent relationships.

\section{Discussion}

Rice is a staple crop and ingredient consumed worldwide. However, the prevalence of rice allergy makes it an important health issue in many countries, especially for those that treat rice as a major diet component [21]. Under several circumstances, the ingestion or inhalation of rice or rice related products result in allergic reactions in atopic individuals, such as those suffering from rhinitis, urticaria, dermatitis, gastrointestinal symptom or asthma [2-10]. A group of rice allergens including $14-16,26,33,56$, and $60 \mathrm{kDa}$ proteins of rice seeds have been identified and proved to be IgE-eliciting in vivo [17-20]. Unlike many other food allergies, there is a dearth of information regarding the molecular mechanisms of rice hypersensitivity reactions largely due to the lack of a validated in vivo model for studying the physiological and immunological mechanisms of the allergic responses elicited by rice.

Here we present a murine model of rice allergy in $\mathrm{BALB} / \mathrm{c}$ mice through daily oral sensitization and multiple challenges. Our model demonstrated an IgEmediated hypersensitivity reaction in mice. In almost all of the experimental mice, the symptoms of hypersensitivity were apparent 1-1.5 h after the fifth i.g. challenge. Symptoms of hypersensitivity included scratching and rubbing around the nose and head, and increased vascular leakage. Elevated RP-specific IgE levels in the sensitized mice and the positive PCA reactions further supported the relevance of the rice allergy mouse model. The phenomenon that the rice allergy caused jejunum inflammation has also been evaluated with the sign of goblet cells hyperplasia in the small intestine, which is consistent with previous reports of food allergy in mice $[22,23]$. However, the current study is limited in discriminating the contribution between rice flour feeding or extracted rice flour protein challenges leading to the observed sensitization. Instead, we mainly described a simple, robust and feasible mouse model for 


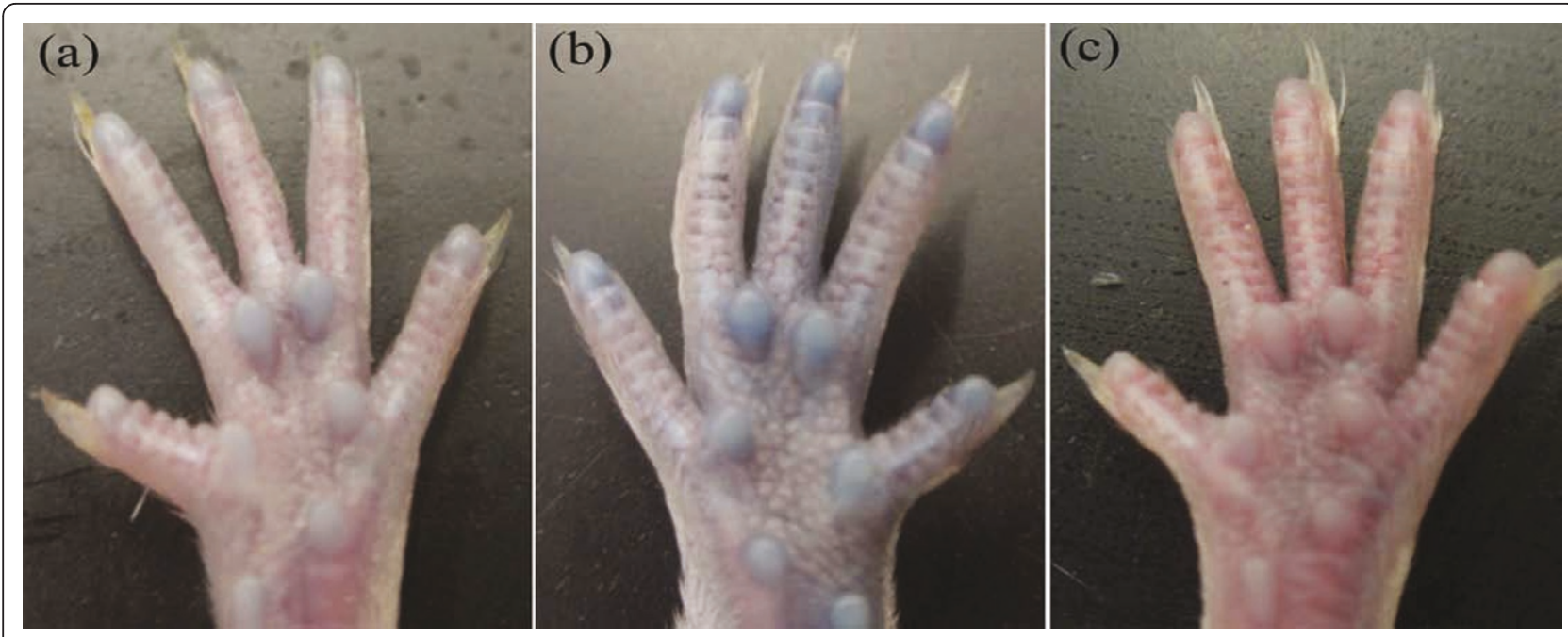

Figure 4 Rice antigen induced vascular leakage. Footpads photographed after Evan's Blue Dye/antigen administration. Bluish coloring of the footpads can be detected in (a, b) mouse daily sensitized with 30 or 80 mg rice seeds flour, respectively. (c) PBS sham-sensitized. This part was assayed in duplicates

evaluation of the rice or other cereal food allergy and possibly for further systematic study of the pathomechanisms of the rice allergy. Moreover, the Th1/Th2 cell-mediated immune responses and other immunobiological patterns have not been addressed in our studies.

There was an increase of rice allergy prevalence in the past decades. Among those reported cases, most were isolated clinical observations of allergenic reactions through contact or ingestion of rice. Alternatively, cross-reactivity of rice with other foods had also been demonstrated in several patients $[24,25]$. The murine model of food allergy, which is regarded as a very useful tool to mimic the allergic reactions in human, has gained promising roles for identification and characterization of proteins responsible in allergy, to better understand the underlying pathogenesis of allergic reactions to food, and for future exploration of new therapeutic approaches [26,27].

Mouse models for different allergens have been published. They could be classified into two major approaches: (i) adjuvant-based or adjuvant-free [28-31], and (ii) sensitized by the intragastric administration or not [32-34]. In the present study, we sensitized and challenged $\mathrm{BALB} / \mathrm{c}$ mice orally without adjuvant trying to mimic the natural way of human daily rice consumption. Moreover, taking into consideration that rice has an in vivo immunogenic capacity through ingestion $[10,35]$, we developed this adjuvant free i.g. sensitization protocol to evaluate the allergenicity of rice. Considering the insoluble property of the prolamin and glutelin fractions of rice in PBS, a relative high dose of total rice protein was used in our protocol to challenge the mice through the i.g. route.

In general, it is believed that high dose of antigen will induce tolerance $[12,36]$. A peanut allergy mouse model study showed that oral administration of $100 \mathrm{mg}$ peanut protein had a significant effect on reducing the level of peanut-specific IgG, IgE, IgG1 and IgG2a [37]. In this study, we employed $30 \mathrm{mg}$ or $80 \mathrm{mg}$ rice seeds flour for sensitization and $30 \mathrm{mg}$ extracted rice flour proteins for challenge. A reason to do so is that both ground rice seeds flour and extracted rice flour proteins contain a mixture of components. Rice allergens comprise a relatively small part of the total rice seeds proteins and the prolamin and glutelin portion are insoluble in PBS. Another concern is that during the oral administration of antigen, the effective dose for allergenic responses to food antigen increased

Table 1 PCA reactions after injection of undiluted pooled sera

\begin{tabular}{cccc}
\hline Donor sensitizaion & Heat inactivation & Diameter $(\mathbf{m m})$ mean \pm SD & Positive reaction sites n/total \\
\hline RP, $30 \mathrm{mg}$ & - & $5.32 \pm 0.83^{*}$ & $12 / 12$ \\
\hline RP, $80 \mathrm{mg}$ & - & $6.96 \pm 0.35^{* * *}$ & $12 / 12$ \\
\hline RP, $80 \mathrm{mg}$ & + & $0.13 \pm 0.10$ & $0 / 6$ \\
\hline PBS & & $0.12 \pm 0.10$ & $0 / 12$ \\
\hline
\end{tabular}

Pooled sera from mice sensitized with RP were injected intradermally into naïve BALB/c mice ( $n=2$ to 4 ) including three antigen and one control injection sites for each mouse. Injection of PBS served as sham control. A positive reaction refers to the skin at the injection sites with bluing greater than 3 mm in diameter. * $\mathrm{P}<0.01$ versus PBS sham control or heated immune sera. ${ }^{* *} \mathrm{P}<0.01$ versus sera from $30 \mathrm{mg}$ RP daily sensitized mice group. All detections were repeated twice. 

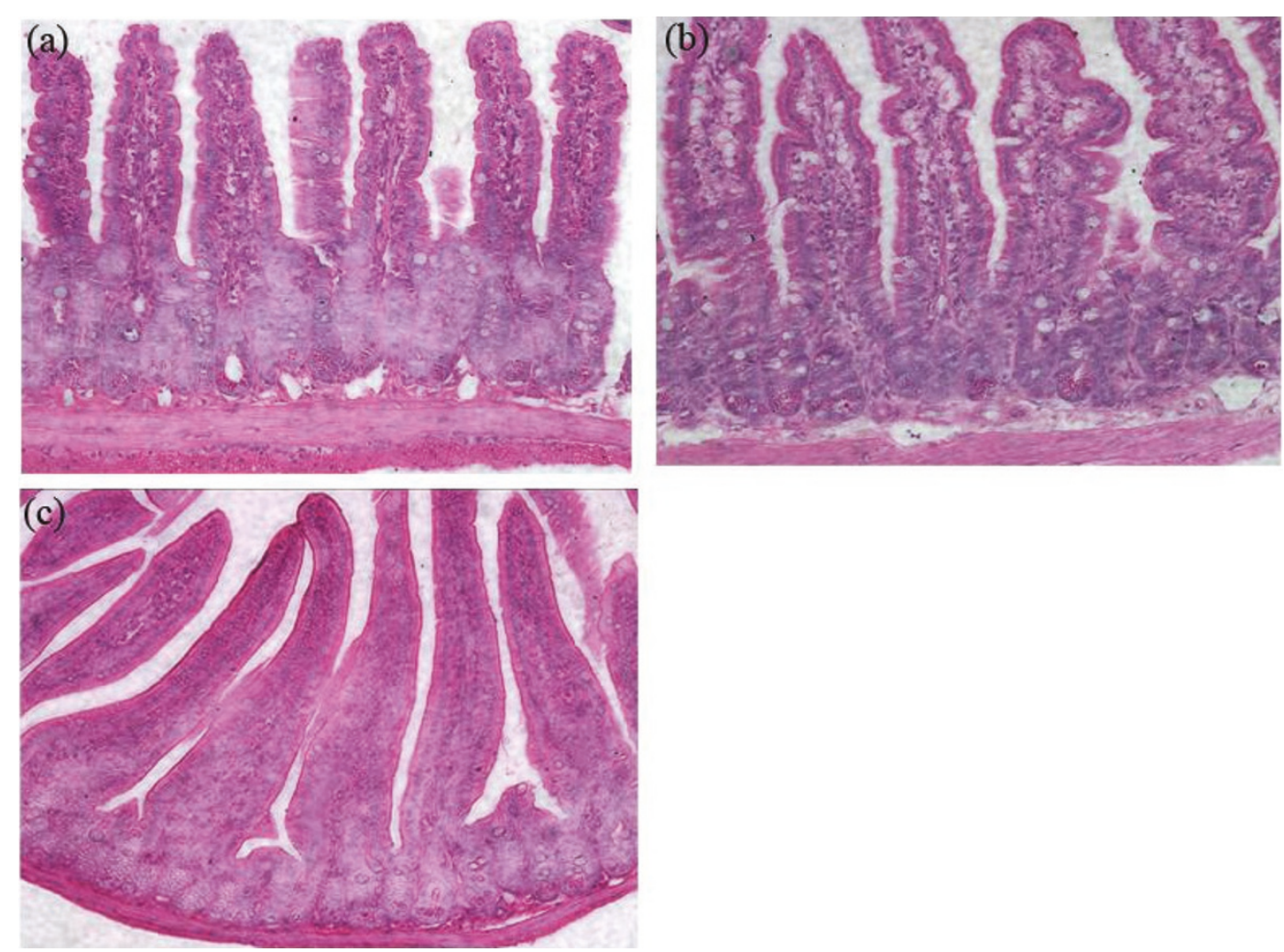

Figure $\mathbf{5}$ Ingestion of rice allergens causes histological alterations. Villi edema, lymphocyte infiltration (white arrows), goblet cells hyperplasia (dark arrow) are shown in the small intestine of BALB/c mice. (a, b) mouse daily sensitized with 30 or 80 mg rice seeds flour, respectively, (c) control mouse with PBS daily sham-sensitization. The H \& E stained sections were photographed through a microscope with 20 times magnification.

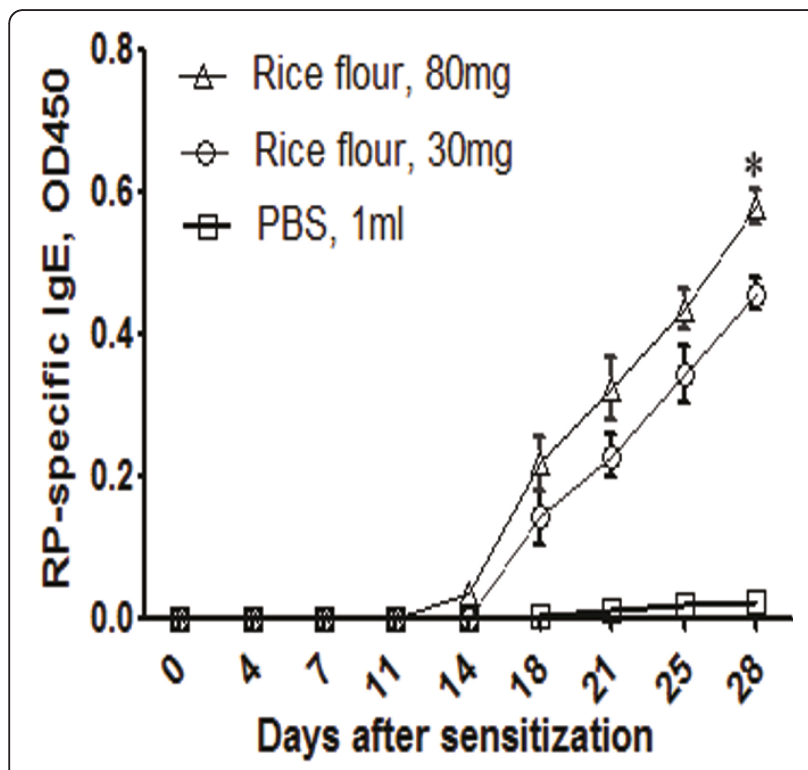

Figure 6 Dose-response and time dependency of RP-specific IgE by ELISA. Sera from different groups of mice $(n=5)$ with the sensitization indicated. The results are presented as mean $\pm \mathrm{SD}$. * rice flour, $80 \mathrm{mg}$ versus rice flour, $30 \mathrm{mg}, \mathrm{P}<0.01$. All samples were assayed in duplicates. mainly because the reaction of food proteins to $\operatorname{IgE}$ decreased through the gastric digestion [38].

\section{Conclusions}

In conclusion, our data demonstrated the efficacy of applying oral administrative method to elicit hypersensitivity in BALB/c mice, in the absence of adjuvant. We described the time- and dose-dependent responses of rice allergy as indicated by the elevated RP-specific IgE level together with the results from passive cutaneous anaphylaxis assay. Furthermore, our experiments which included multiple identified rice seeds allergens and a large fraction of rice seeds proteins during the course of sensitization, may provide a more holistic view on the allergenicity of rice. This model may be useful in future studies for the underlying mechanisms of allergy caused by rice or other cereals, the evaluation of allergenic candidates in rice or other cereals and the development of immunotherapy in allergy-related diseases.

\section{Acknowledgements}

We thank Wai-Kwan Kwok and Man-Kin Hung for excellent technical assistance, and Chung Sing Wong for revising the manuscript. This work was 
supported by a grant from the University Grants Committee of the Hong Kong Special Administrative Region, China (Project No. AoE/B-07/99).

\section{Authors' contributions}

XWC and MCF designed the study. XWC carried out the experiments, and prepared the manuscript. KWKL coordinated the study, helped with the experiments and critically revised the manuscript. FY contributed ideas in protein extraction and mouse model establishment. SSMS and MCF conceived, coordinated the study and critically revised the manuscript. All authors read and approved the final manuscript.

\section{Competing interests}

The authors declare that they have no competing interests.

Received: 6 July 2010 Accepted: 23 May 2011 Published: 23 May 201

\section{References}

1. Khush G: Productivity improvements in rice. Nutr Rev 2003, 61:S114-116.

2. Kumar R, Srivastava P, Kumari D, Fakhr H, Sridhara S, Arora N, Gaur SN, Singh BP: Rice (Oryza sativa) allergy in rhinitis and asthma patients: a clinico-immunological study. Immunobiology 2007, 212:141-147.

3. Lezaun A, Igea JM, Quirce S, Cuevas M, Parra F, Alonso MD, Martin JA, Cano MS: Asthma and contact urticaria caused by rice in a housewife. Allergy 1994, 49:92-95.

4. Orhan F, Sekerel BE: A case of isolated rice allergy. Allergy 2003, 58:456-457.

5. Shibasaki M, Suzuki S, Nemoto $H$, Kuroume T: Allergenicity and lymphocyte-stimulating property of rice protein. J Allergy Clin Immunol 1979, 64:259-265.

6. Arai T, Takaya T, Ito Y, Hayakawa K, Toshima S, Shibuya C, Nomura M, Yoshimi N, Shibayama M, Yasuda Y: Bronchial asthma induced by rice. Intern Med 1998, 37:98-101.

7. di Lernia V, Albertini G, Bisighini G: Immunologic contact urticaria syndrome from raw rice. Contact Dermatitis 1992, 27:196.

8. Fiocchi A, Bouygue GR, Restani P, Gaiaschi A, Terracciano L, Martelli A Anaphylaxis to rice by inhalation. J Allergy Clin Immunol 2003, 111:193-195.

9. Mehr SS, Kakakios AM, Kemp AS: Rice: a common and severe cause of food protein-induced enterocolitis syndrome. Arch Dis Child 2009, 94:220-223.

10. Nowak-Wegrzyn A, Muraro A: Food protein-induced enterocolitis syndrome. Curr Opin Allergy Clin Immunol 2009, 9:371-377.

11. Dearman RJ, Kimber I: Animal models of protein allergenicity: potential benefits, pitfalls and challenges. Clin Exp Allergy 2009, 39:458-468.

12. Kimber I, Dearman RJ, Penninks AH, Knippels LM, Buchanan RB, Hammerberg B, Jackson HA, Helm RM: Assessment of protein allergenicity on the basis of immune reactivity: animal models. Environ Health Perspect 2003, 111:1125-1130

13. Ju ZYHN, Rath N: Extraction, Denaturation and Hydrophobic Properties of Rice Flour Proteins. J Food Science 2001, 66:229-232.

14. Golde WT, GPRL: A rapid, simple, and humane method for submandibular bleeding of mice using a lancet. Lab Anim (NY) 2005, 34:39-43.

15. Li XM, Schofield BH, Huang CK, Kleiner Gl, Sampson HA: A murine model of IgE-mediated cow's milk hypersensitivity. J Allergy Clin Immunol 1999, 103:206-214.

16. Saloga J, Renz H, Lack G, Bradley KL, Greenstein JL, Larsen G, Gelfand EW: Development and transfer of immediate cutaneous hypersensitivity in mice exposed to aerosolized antigen. J Clin Invest 1993, 91:133-140.

17. Ikezawa Z, Tsubaki K, Osuna H, Shimada T, Moteki K, Sugiyama $H_{\text {, }}$ Katumata K, Anzai H, Amano S: Usefulness of hypoallergenic rice (AFT-R 1) and analysis of the salt insoluble rice allergen molecule. Arerugi 1999 , 48:40-49.

18. Nakase M, Usui Y, Alvarez-Nakase AM, Adachi T, Urisu A, Nakamura R, Aoki N, Kitajima K, Matsuda T: Cereal allergens: rice-seed allergens with structural similarity to wheat and barley allergens. Allergy 1998, 53:55-57.

19. Usui $Y$, Nakase M, Hotta H, Urisu A, Aoki N, Kitajima K, Matsuda T: A 33-kDa allergen from rice (Oryza sativa L. Japonica). cDNA cloning, expression, and identification as a novel glyoxalase I. J Biol Chem 2001, 276:11376-11381.
20. Gabriel G, Limas MS, Moneo Ignacio, Fischer Stefan, WittmannLiebold Brigitte, Méndez Enrique: Purification and characterization of ten new rice $\mathrm{NaCl}$-soluble proteins: identification of four protein-synthesis inhibitors and two immunoglobulin-binding proteins. Planta 1990, 181:1-9.

21. Ikezawa Z, Miyakawa K, Komatsu H, Suga C, Miyakawa J, Sugiyama A, Sasaki T, Nakajima H, Hirai Y, Suzuki Y: A probable involvement of rice allergy in severe type of atopic dermatitis in Japan. Acta Derm Venereol Suppl (Stockh) 1992, 176:103-107.

22. Nakajima-Adachi H, Ebihara A, Kikuchi A, Ishida T, Sasaki K, Hirano K, Watanabe H, Asai K, Takahashi Y, Kanamori Y, et al: Food antigen causes $\mathrm{TH} 2$-dependent enteropathy followed by tissue repair in T-cell receptor transgenic mice. J Allergy Clin Immunol 2006, 117:1125-1132.

23. Pali-Scholl I, Yildirim AO, Ackermann U, Knauer T, Becker C, Garn H, Renz H, Jensen-Jarolim E, Fehrenbach $\mathrm{H}$ : Anti-acids lead to immunological and morphological changes in the intestine of $B A L B / c$ mice similar to human food allergy. Exp Toxicol Pathol 2008, 60:337-345.

24. Asero R, Amato S, Alfieri B, Folloni S, Mistrello G: Rice: another potential cause of food allergy in patients sensitized to lipid transfer protein. Int Arch Allergy Immunol 2007, 143:69-74.

25. Lehrer SB, Reese G, Malo JL, Lahoud C, Leong-Kee S, Goldberg B, Carle T, Ebisawa M: Corn allergens: IgE antibody reactivity and cross-reactivity with rice, soy, and peanut. Int Arch Allergy Immunol 1999, 118:298-299.

26. Helm RM, Burks AW: Animal models of food allergy. Curr Opin Allergy Clin Immunol 2002, 2:541-546.

27. Lehrer SB, McClain S: Utility of animal models for predicting human allergenicity. Regul Toxicol Pharmacol 2009, 54:S46-51.

28. Birmingham NP, Parvataneni S, Hassan HM, Harkema J, Samineni S, Navuluri L, Kelly CJ, Gangur V: An adjuvant-free mouse model of tree nut allergy using hazelnut as a model tree nut. Int Arch Allergy Immunol 2007, 144:203-210.

29. Gonipeta B, Parvataneni S, Paruchuri P, Gangur V: Long-term characteristics of hazelnut allergy in an adjuvant-free mouse model. Int Arch Allergy Immunol 2010, 152:219-225.

30. Capobianco F, Butteroni C, Barletta B, Corinti S, Afferni C, Tinghino R, Boirivant M, Di Felice G: Oral sensitization with shrimp tropomyosin induces in mice allergen-specific lgE, $\mathrm{T}$ cell response and systemic anaphylactic reactions. Int Immunol 2008, 20:1077-1086.

31. Leung PS, Lee YS, Tang CY, Kung WY, Chuang YH, Chiang BL, Fung MC, Chu $\mathrm{KH}$ : Induction of shrimp tropomyosin-specific hypersensitivity in mice. Int Arch Allergy Immunol 2008, 147:305-314.

32. Vinje NE, Larsen S, Lovik M: A mouse model of lupin allergy. Clin Exp Allergy 2009, 39:1255-1266.

33. Valeur J, Lappalainen J, Rita H, Lin AH, Kovanen PT, Berstad A, Eklund KK, Vaali K: Food allergy alters jejunal circular muscle contractility and induces local inflammatory cytokine expression in a mouse model. BMC Gastroenterol 2009, 9:33.

34. Dearman RJ, Kimber I: A mouse model for food allergy using intraperitoneal sensitization. Methods 2007, 41:91-98.

35. Wuthrich B, Scheitlin T, Ballmer-Weber B: Isolated allergy to rice. Allergy 2002, 57:263-264.

36. Dearman RJ, Stone S, Caddick HT, Basketter DA, Kimber I: Evaluation of protein allergenic potential in mice: dose-response analyses. Clin Exp Allergy 2003, 33:1586-1594.

37. Strid J, Thomson M, Hourihane J, Kimber I, Strobel S: A novel model of sensitization and oral tolerance to peanut protein. Immunology 2004 113:293-303.

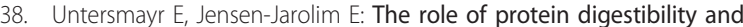
antacids on food allergy outcomes. J Allergy Clin Immunol 2008, 121:1301-1308, quiz 1309-1310.

\section{Pre-publication history}

The pre-publication history for this paper can be accessed here: http://www.biomedcentral.com/1471-230X/11/62/prepub

\section{doi:10.1186/1471-230X-11-62}

Cite this article as: Chen et al:: An adjuvant free mouse model of oral allergenic sensitization to rice seeds protein. BMC Gastroenterology 2011 11:62. 